\title{
Invisible Man: Somebody's Protest Novel
}

Thomas A. Vogler

This simply because I had a notion it somehow would be of help to that Kurtz whom at the time I did not see-you understand. He was just a word for me. I did not see the man in the name any more than you do. Do you see him? Do you see the story? Do you see anything? - Conrad

Oh say can you see ...? (National Anthem)

With Hemingway and Faulkner both dead, this is not a time of recognized literary giants. The public, and critics too, are too easily preoccupied with literary giantism, with finding the next heir to the vacated throne. Publishers want their books to sell, and are not very timid about making claims. Readers want to feel that what they are reading is what they ought to be reading, in terms that can only be reached from the vantage point of a historical perspective. Our contemporary writers should, however, be looked on and cherished as partly-realized potential, writers whose work should not be idolized too much, nor ignored, but read with the best awareness we can bring to them of their relationships to our own lives and to the traditions they continue. Melville seemed to be a distinctly minor writer to his own age. In 1945 all seventeen of Faulkner's books were out of print. We should be chastened and warned by examples like these, but not overly frightened in our attempts to find something of value in our contemporary writers.

With the belated advent of "Black Literature" it has become even more difficult to find a long-term context in which to read or discuss a novel like Invisible Man. Its relevance to the contemporary social problems of Black citizens can be used to reduce it to the level of a documentary of the Black experience. ${ }^{1}$ On the other hand, its insistence on craft and analysis, its careful avoidance of the explicit advocation of action, can be passed off by the activists as the "buggy jiving" of a white middle-class sellout, or the ravings of a private ego trip. This latter trend is accurately prophesied at the every end of the novel. ${ }^{2}$ Most intolerable, perhaps, is the approach taken by some critics of both colors, that the novel is "pure" art, that a Negro writer has finally written his way into the mainstream of some etherealized literary tradition. ${ }^{3}$

In spite of the present existence of what Time magazine calls, in the jargon of the literary stockmarket, a "modest literary boom," these are not good times for 
writers. There are as many kinds of literary suicide available as there are writers, and the hardest thing seems to be, not to write the first novel, but to remain at the craft, writing for one's self and for the one imaginary reader who will understand, rather than for the publisher, the editor, the reviewer, the agent, the publicist, and the novelty-seeking audience they serve. But it is not enough of a problem for the writer to be in an arena where public relations men largely determine whether his book will sell less than 5,000 or more than 100,000 copies. There is also the problem of the critics, who are committed in their own way to thinking of the literary stockmarket. Critics quite easily become obsessed with what is for them the counterpart to the writer's creative urge. This is the desire to find patterns comprehensive enough to include everything that is good, and it is a reasonable enough urge when followed with discrimination. But too easily the pattern becomes a definition of what is good, and good writers get lost or distorted because they do not fit the mold. The critic of contemporary writers is especially vulnerable to this mistake. As Norman Mailer pointed out, it is "naturally wiser for the mind of the expert to masticate the themes of ten writers, rather than approach the difficulties of any one."

In many ways, then, to talk about a contemporary novel like Invisible Man involves problems different from those we face when discussing a novelist like Wharton or Fitzgerald. On the other hand, no really good writer can be completely contemporary without serious limitations. The kind of synthesis and evaluation of experience that we expect in a good novel cannot be contemporary with the experience itself. In addition, Ellison has roots in the 19th century that are at least as important as those in the 20th; what he writes is as much influenced by what he has read as it is by what he has seen and lived through. Though Ellison is close to Hemingway in many ways, and even copied his stories by hand in order to develop an understanding of his style, he seems to bear an even more important relationship to Melville. Ellison uses two quotations as epigraphs at the beginning of Invisible Man. One, from Melville's Benito Cereno, suggests the nature of the change the invisible man undergoes in the novel. The other, from Eliot, suggests the discovery of his invisibility which is an essential part of the change. Before discussing invisibility and change, however, I would like to suggest another passage, also from Melville, which will help to get at some of the more negative aspects of the book-for Ellison, like Melville, understood that fiction must be negative in order to fulfill both its artistic and moral obligations:

There is the grand truth about Nathaniel Hawthorne. He says NO! in thunder; but the devil himself cannot make him say yes. For all men who say yes, lie; and all men who say no,-why they are in the happy condition of judicious, unincumbered travellers in Europe; they cross the frontiers into Eternity with nothing but a carpetbag-that is to say, Ego.

There is a nice comparison here with the invisible man, who crosses his frontier into the darkness with a briefcase containing all the clues to his identity or "Ego"; but the passage also suggests the dark impulse of resistance which con- 
tinues to permeate contemporary fiction in works like Invisible Man. The novelists seem to agree that violence and distortion must be the means of projecting a vision to which society is hostile. They seem further to agree that the contemporary world presents a continued affront to man, and that his response must therefore be at least in part that of the rebel.

There is a standard psychological experiment known to produce neuroses and psychopathic behavior patterns in most domestic or trainable animals. In an experimental environment that bears a striking resemblance to the world of the novel, the animals are trained to react in certain ways to certain stimuli, and then placed in a situation in which the reactions are impossible. The animal then makes what attempts it can to go on acting as it has been trained to do, but with continued frustration a nervous collapse of some kind inevitably follows. With some, the reaction is solipsistic-they refuse to mix with other animals even for eating. Others react by batting their heads against the walls of their cages until they die or are too exhausted to continue. The equivalent experience of conflict between expectations and reality has produced what Ellison calls "the American Negro impulse toward self-annihilation and going underground," which can only be overcome by "a will to confront the world, to evaluate his experience honestly and throw his findings unashamedly into the guilty conscience of America."4 His Invisible Man is a record of that agony, and of the discovery of the realities that must be faced before a genuine identity can be achieved.

But I think the memoir, which is titled Invisible Man, his memoir, is an attempt to describe reality as it really exists rather than in terms of what he had assumed it to be. Because it was the clash between his assumptions, his illusions about reality, and its actual shape which made for his agony. 5

In the novel we see the kind of training the invisible man is subjected to most clearly in the chapel scene in Chapter 5. Here are Barbee's concluding remarks, holding up Bledsoe as the pattern for the hero to follow:

His is a form of greatness worthy of your imitation. I say to you, pattern yourselves upon him. Aspire, each of you, to someday follow in his footsteps.

In the next chapter, Bledsoe tries to explain to the invisible man what he calls "the difference between the way things are and the way they're supposed to be," but it is a lesson he is not yet prepared to learn. The invisible man, like most of us, is living in a culture whose incentives, rewards and punishments prevent the development of the kind of personal standards which the public ideals demand for a feeling of self-respect. He is in the situation Paul Goodman describes in Growing up Absurd, where the only truly healthy response is to reject those parts of society that threaten his own possibilities for self respect. But he cannot reject them without knowing what they are, and they are built in so that he is himself responsible for much of what he must go through. 
To call a novel a protest novel at this point of history is inevitably to call back the thirties and the great American discovery of social injustice. The roots of much in Invisible Man are to be found in this period, in writers like Dos Passos, Steinbeck, Farrell, Hemingway (at least in For Whom the Bell Tolls), and especially Richard Wright. During the forties there was a decline in novels dealing primarily with the social themes of the thirties; during this period, however, there was a constant discovery of new areas of social disorganization which novelists adopted for the focus of their works. The war experience was another catastrophe, piled on top of the depression, which the American novelist had to cope with in his attempts to find a view of his place in society. Another discovery during this period-and a much belated one-was of the extent and complexity of the social problems of the Negro, and of the essential part these problems took in any attempt to achieve an overall view of American society. The development of the Negro novel is not adequately explained by a theory of growing liberalism, or a shedding of prejudice which now makes white readers willing to read books they know were written by Blacks. It is not even clear that the early publishers, who disguised the fact that particular novels were written by Blacks, were acting realistically-but that's beside the point. What is clear is that in the 20th century, as in the 19th, the position of the Black citizen in our society is the focus of social and ideological polarities that go far beyond the question of race relations. It is also the focus for many of the neurotic fears and desires that are an inevitable part of our gross national product. From Richard Wright's first novel on, the movement has not been a shedding of prejudice, but a growing awareness, in writers and readers alike, of the essential centrality of the Black problem to any adequate view of American society.

Negro life is a byproduct of Western civilization, and in it, if only one possesses the humanity and humility to see, are to be discovered all those impulses, tendencies, life and cultural forms to be found elsewhere in Western society. ${ }^{6}$

It is in this way that Black writers have been developing and expressing an awareness of the universal significance of their position, as Faulkner had earlier found in a single southern county all the elements necessary to an understanding of human nature and the movement of history. Ellison is like Faulkner in seeing the South as a land doomed by the curse of slavery, yet still with a vestigial aura of Edenic simplicity. But Ellison follows his Black hero out of the South, as Wright had done, and is much more concerned than Faulkner with a direct consideration of the relationship of the civil war to all aspects of contemporary society, both North and South.

It would be too simple a view to consider the function of the Black protagonist as merely that of another outsider who can serve as a foil to define weaknesses in the social structure. The situation of the Black, like that of the writer, is a part of the society and reveals important things about it.

Anyway, in the beginning I thought that the white world was very different from the world I was moving out of and I turned out to be 
entirely wrong. It seemed different. It seemed safer, at least the white people seemed safer. It seemed clearer, it seemed more polite, and, of course, it seemed much richer from the material point of view. But I didn't meet anyone in that world who didn't suffer from the very same affliction that all the people I had fled from suffered from and that was that they didn't know who they were. They wanted to be something that they were not. And very shortly I didn't know who I was, either. I could not be certain whether I was really rich or really poor, really black or really white, really male or really female, really talented or a fraud, really strong or merely stubborn. In short, I had become an American. ${ }^{7}$

The final test of the mastery of illusion and reality, and the discovery of an identity, is the ability to tell it. This is not the novelist's prerogative, as the examples of Malcolm X and Eldridge Cleaver show, and as Ellison suggests in Brother Tarp's recognition of the "signifying" embodied in his chain link and his pleasure at finally being able to communicate his story to the invisible man ("I'm tellin' it better'n I ever thought I could!"). If Ellison has entered the mainstream of modern art, it is through his fusion of the problems of his Black protagonist with those of the writer, whose search for form and reality is the central problem of most serious writers of fiction in the last 100 or so years. In an eloquent mood, Ellison has spoken to the best hopes of most novelists of whatever color:

Life is as the sea, art a ship in which man conquers life's crushing formlessness, reducing it to a course, a series of swells, tides and wind currents inscribed on a chart. Though drawn from the world, "the organized significance of art," writes Malraux, "is stronger than all the multiplicity of the world; . . . that significance alone enables man to conquer chaos and to master destiny." 8

Invisible Man is not 'just' a Negro novel, then, and Ellison has been very careful throughout to avoid this tempting limitation, even while giving us a very comprehensive view of race relations in both the South and the North. Look for a moment at Tod Clifton, remembering that it is no accident that Tod in German means "death." Tod is part black, part white, symbolically gray like the "Liberty Paint" that goes out of the factory to decorate some important national monument. Tod's death is one of the key turning points of the book, forcing the invisible man to the recognition that we all shall die, leading finally to the recognition that, in an absurd society, it is an error to cater to any but one's own unique absurdity. His reflections on Tod's death are a turning-point from which he intensifies the exploration of his own identity and begins to recognize more fully the possible identities of others. In the crowd at the funeral oration he sees individual faces, marked with suffering that he begins to understand:

Here are the facts. He was standing and he fell. He fell and he kneeled. He kneeled and he bled. He bled and he died. He fell in a 
heap like any man and his blood spilled out like any blood; red as any blood, wet as any blood-and it dried in the sun as blood dries. That's all.

The specific racial killing of a Black man becomes more than the death of an individual caused by social injustice. It is the death of the best parts of the individual caused by the worst parts of society; it is "OUR HOPE SHOT DOWN," for on the lower frequencies Ellison has been speaking for us all.

In Invisible Man we have a full portrait of the element of despair and of the destructive element forced on the Black, the writer, and on us as well if we go along. The question we are deliberately left with, in the end which is also a beginning, is the constructive use to which these elements can be put-the role for the self which has at last been recognized and accepted, the kind of life one can live in a realm of absurdity which is also a realm of possibility. The problem of how all this negation can be put to use is already answered in part by the very existence of the novel. It is emphasized in the beginning and end that the protagonist of the book is also its creator, and that the writing of the book is itself part of the experience, and of the discovery of an identity, which is the subject of the book. What is affirmative in both the structure and the existence of the book is that the invisible man does survive through turning his experience into art. In the same way, the ordinary Black in a hostile society has been able to turn daily injustice and suffering into the folk art of the blues. The novel, like the blues, offers a way of standing apart from one's experience without losing its intensity or its meaning. All Black writers have agreed that the blues have been a survival mechanism for the Negro in America and also that they have been the most important cultural contribution to American art. For Ellison, the blues "is an impulse to keep the painful details and episodes of a brutal experience alive in one's aching consciousness, to finger its jagged grain, and to transcend it, not by the consolation of philosophy, but by squeezing from it a neartragic, near-comic lyricism." The blues recognizes both the painful and contradictory aspects of experience, turning them into something like a joke. "There is a mystery in the whiteness of blackness, the innocence of evil, and the evil of innocence, though, being initiates, Negroes express the joke of it in the blues." The acceptance is finally achieved only in terms of artistic expression, whether it be in the blues or in the form and creation of a novel. In the book itself, this analogy with the blues is continually suggested. In some cases, as in the college chapel scene, the blues can be an expression of hope:

I closed my eyes as I heard the deep moaning sound that issued from him, and the rising crescendo of the student body joining in. This time it was music sincerely felt, not rendered for the guests, but for themselves; a song of hope and exaltation. I wanted to rush from the building, but didn't dare. I sat stiff and erect, supported by the hard bench, relying upon it as upon a form of hope.

In other cases, such as the singing at Tod Clifton's funeral, the invisible man 
comes closer to recognizing the sense of blues that Ellison was getting at in his definition. Here is his reaction to the man who starts the singing:

I looked into the face of the old man who had aroused the song and felt a twinge of envy. It was a worn, old, yellow face and his eyes were closed and I could see a knife welt around his upturned neck as his throat threw out the song. . . . I watched him now, wet-eyed, and I felt a wonder at the singing mass. It was as though the song had been there all the time, and he knew it and aroused it; and I knew that I had known it too, and had failed to release it out of a vague, nameless shame or fear. Even white brothers and sisters were joining in. Something deep had shaken the crowd, and the old man and the man with the horn had done it. They had touched upon something deeper than protest or religion. It was not the words, for they were all the same old slave-borne words: it was as though he'd changed the emotion beneath the words while yet the old longing, resigned, transcendent emotion still sounded above, now deepened by that something for which the theory of brotherhood had given me no name.

The invisible man has found something here that the conscious quest for identity had failed to reveal. It is only after this discovery that he is able to make of his writing the same use that the singer makes of the blues. It is a means of achieving an acute sense of identity and self-recognition that society has been unable to provide. ${ }^{9}$

This discovery of the potential for self discovery in the blues, or in a novel which approaches them in spirit, comes on the invisible man almost unawares, in spite of the more literary and more conscious quest for identity that he has been pursuing before. Sooner or later it seems that almost every modern work can in some way be read as a search-or more typically a "quest"-for a father or a mother. The two concepts are not interchangeable; they offer primitive but different solutions to man's basic need to reach beyond his own mind and find some fixed point around which to orient his own existence. The search for a father is almost always for a principle of authority, a lawgiver of some kind, even if it is the stern inscrutability of some abstract principle of necessity. In the earlier part of Invisible Man we find figures like the Founder and Bledsoe, and the great white father figures of Norton and the other trustees. Even the Brotherhood, at first felt as a fraternity of equality and freedom, is finally seen to be dominated by a harshly paternal theory of history, and Brother Jack turns out to be a disguised father masquerading as a brother. The mother figure typically offers an alternative orientation for experience, and has something that is always missing or of lesser importance in the father figures. The strictness of the father is replaced by the all-embracing acceptance of the mother, who refuses to reject her child no matter how poor, weak or sinful he has become. In Invisible Man the landlady Mary who takes up the hero and keeps him and feeds him is such a figure. He is trying to reach Mary's when he falls down the hole at the end, and it is to Mary's that his feet had unconsciously taken him earlier in the book: 
But I was never to reach Mary's. And now I realized that I couldn't return to Mary's, to any part of my old life, I could only approach it from the outside, and I had been as invisible to Mary as I had been to the brotherhood.

The recognition that he can't return to Mary, that the alternative she suggests, with all its religious overtones, is as unattainable as that offered by the series of fathers, is paralleled by the tone and structure Ellison uses to handle the theme in the novel. The invisible man's search for a father or a mother is a reflex in him, and therefore an inevitable part of his experience and a necessary part of the novel. But if the novel must go through the quest because its protagonist must go through, it can at least do it in a different way. Ellison has pointed out that "When you are influenced by a body of literature or art from an earlier period, it is usually the form of it that is available to you," and he has openly acknowledged the high degree of literary self-consciousness manifest in the novel. "Let's put it this way-I'm a highly conscious writer. I know what's been done because I've read the books, I've studied them."10 The consciousness of form and archetype leads to a deliberate and parodic use of such patterns in Ellison's work, and contributes to its enlightened literary humor. The invisible man may be duped into questing after unattainable or irrelevant goals, but he will not let his novel make the same mistake. The more innovative quest in Invisible Man is not that for a father or a mother, but the search for a group, a fraternity, a brotherhood of fellow humans in which the invisible man can find his identity and achieve the freedom and dignity which are the real goals of his quest. The final irony of this quest is that the real brotherhood, that of all humans facing death and oppression, can be joined only by renouncing all fictitious bases of brotherhood. In every alternative but this, the invisible man must repress part of his emotions and his humanity-the group of Black boys in the battle-royal, his fellow-students, the union, the catch-all fraternity of the Harlem Men's House, the disguised paternal system of the Brotherhood, the Black fraternity of Ras the Exhorter-Destroyer-all of these offer roles which he either cannot accept or which demand that he sacrifice too much of himself to find a genuine identity in membership.

As he moves from one tentative role to another, he attempts to cast off earlier parts of his identity which the new roles cannot accept. Simultaneously with becoming a brother, he tries to discard the bank which is an image of different kinds of dependencies. "Feed me," the bank says on its front, and it reminds us of all the Black entertainers who have publicly distorted themselves into this gross caricature, just as the invisible man's attempt to destroy the bank suggests the corps of jazz musicians who have refused to smile while playing in order to prevent associations with the old image from coming back to destroy the dignity of their art. In spite of his attempts, the invisible man cannot get rid of the bank. A white woman, and a white man, force him to retrieve it first out of the garbage and then off the street. So he seals it up in the briefcase with all the other clues to the identity which he refuses to accept. The briefcase is an emblem of himself, a container of images which he hates but cannot lose: 
"What's in that briefcase," they said, and if they'd asked me anything else I might have stood still. But at the question a wave of shame and outrage shook me and I ran.

This is the same question the doctors were asking him earlier, only now he is ready to find the answer. He is forced, in the darkness of his hole, to explore the contents of the briefcase which are the real clues to his identity and the only source of light.

The exploration, as I have already suggested, is undertaken in the act of telling the story. In this exploration the big issues are the problems of politics, of freedom, of brotherhood, of the rejection of a father and the loss of a mother, the distrust of rhetoric and abstractions which dilute experience and disguise reality. All of these issues are elements in the formal pattern and structure of the novel. But all of these are tied together by the central problem of finding his identity. Until he finds it, the invisible man is like a cup of water without the cup; he takes on his identity from whatever shape his environment offers until, finally, he realizes that his once new and clean briefcase, now battered and dirty, is symbolically the container of all the clues that are essential to finding his true identity. This chameleon-like flexibility is one of the most typically American features in the whole book, and it is perhaps our best clue to Ellison's identity as an American writer. From the legendary versatility of Benjamin Franklin, through innumerable characters in Irving, Hawthorne, Melville, Whitman and Twain, there is the concept of a character who can move from one identity to another without effort, preparation or reflection. This concept is so basic that it turns up both in the traditions and idealized national myths-characters like Franklin and Alger-and in the works of writers like Ellison who are rebelling from the hypocrisy of those ideals while still realizing that metamorphosis is a basic fact and possibility of existence. It can be a debased, almost subhuman instrument of survival, as in Faulkner's Snopes family, or it can be a social triumph as in the legendary founder of the invisible man's college. It can be the source of humor, as in Huckleberry Finn, or the more cosmic and ironic humor of Melville's Confidence Man.11

At a crucial point in the novel the invisible man "discovers" this principle of metamorphosis which has been there all along. At first, he is impressed by the world of possibilities opened up before him:

Well, I was and yet I was invisible, that was the fundamental contradiction. I was and yet I was unseen. It was frightening and as I sat there I sensed another frightening world of possibilities. . . . Perhaps I could tell them to hope until I found the basis of something real, some firm ground for action. . . . But until then I would have to move them without myself being moved. . . . I'd have to do a Rinehart.

So he tries to Rinehart it; he will find a woman in the Brotherhood and use her to gain inside information about their plans. Unfortunately for the invisible man he picks Sybil for his informant, and she has the enthusiastic frenzy but lacks 
the information he is looking for. ${ }^{12}$ Instead, she merely gives him another lesson in his invisibility. She looks through him and sees nothing but her own fantasy of the Black phallus, the Negro rapist. And since he is now "doing a Rinehart" as he puts it, operating in the world of possibility, he can convince her-or let her convince herself-that she was raped without actually doing it. "sYBIL, YOU WERE RAPED BY SANTA CLAUS SURPRISE" he writes on her bare belly. And the image is a perfect one, for her fantasy of him is no more real than the child's fantasy. She has been taught to believe in the Black sex fantasy as the child is taught to believe in the great magic gift-giver. ${ }^{13}$

There is an interesting example of the precision and economy of Ellison's characterization in this episode. There are two sexual adventures in the book, and they both serve distinct functions. The first adventure occurred when the invisible man was sent down town to lecture on "The Woman Question," only to find out that the real question was the one Ras had asked earlier, when trying to understand what could move a Black to join the Brotherhood. What is it, Ras asks, money or women, that is confusing the invisible man's ideology. The woman who seduces him in her apartment is confusing the concept of brotherhood with biology, offering in fact still another alternative that he must try and then reject during the novel.

Why did they have to mix their women into everything? Between us and everything we wanted to change in the world they placed a woman: socially, politically, economically. Why, godammit, why did they insist upon confusing the class struggle with the ass struggle, debasing both us and them-all human motives.

This is the other side of the confusion that Ras showed on the woman question. They both attribute a sexual motivation to a drive to attain social equality and human dignity.

The principle of invisibility and projected fantasy which we have seen operating in these episodes-and which the invisible man is gradually discovering-was announced on the first page of the novel. It is "a peculiar disposition of the eyes of those with whom I come in contact. A matter of the construction of their inner eyes, those eyes with which they look through their physical eyes upon reality." The consequence of this disposition of the inner eye for the invisible man is not that people see nothing at all when they look in his direction, for they know that something is there. What they do is look through that something at what they expect to see, what they think is there-the inner eye sees a fiction that it has itself created. The first concrete example of this error of vision comes in the Prologue, when the invisible man bumps into a tall blond man who insults him and curses him when asked to apologize. In the fight that follows the white man is almost killed, but not by the invisible man. "Something in this man's thick head had sprung out and beaten him within an inch of his life," and that something was the man's own prejudiced concept of the Nigger which he had insulted and cursed.

The Prologue also introduces the problem of names which the reader encounters with almost every character, and the critic suffers while trying to write about 
the nameless protagonist of the novel. Thoreau once wrote an essay largely devoted to praising the system of naming practiced by the American Indians. What Thoreau admired about the system was the idea that everyone had to wait until he had earned a name through some significant action, or until he had revealed enough of his basic personality for a name to be chosen that adequately reflected his individuality. The "invisible man" is an earned name in something like the same sense, as "Jack the Bear" is his underground name because he sees his underground time as a period of hibernation. Most of the names we are given for characters in the novel are also earned names, or names which serve as clues to the character's nature or his function in the novel. Sometimes these names are symbolic, like "Tod" Clifton or "Mary." More often they are not so much directly symbolic as suggestive.

For example, when we look at Brother Jack, we should remember that a common slang meaning for "jack" is money. The name emphasizes the financial element in the relationship between the invisible man and the Brotherhood. When Ras ("race") the Exhorter asked whether it was money or women that could blind a Negro to his racial identity, the invisible man was outraged that his purity of motive could be questioned. But the whole scene takes place in front of a garish sign that says "CHECKS CASHEd HERE." Brother Jack first showed up when the invisible man was out of money, and his first reason for joining the Brotherhood was for the pay they offered. Without knowing it, at the same time as he is trying to get rid of the bank because it is the image of the paid entertainer debasing himself for money, he is taking on an analogous position within the Brotherhood. This is emphasized at the end, when Brother Jack is disciplining him. ". . . you were not hired to think. Had you forgotten that? If so, listen to me: You were not hired to think."

Rinehart is another significant name, but it can be misleading if one looks to the German rein ("pure") for help. "Rind" (or "rine" in the pronunciation of the novel) is a good American slang word. If a person has a lot of rind, it means he has a lot of nerve. If he is a rind, it means he is thick-skinned in a sense ranging all the way from not caring what other people think to not caring what happens to them. This is the rind in the Rinehart in the novel, and the invisible man points to it just before hunting up Sybil:

Now I recognized my invisibility. So I'd accept it, I'd explore it, rine and heart. I'd plunge into it with both feet and they'd gag. Oh, but wouldn't they gag.

As it turns out, however, it is the invisible man who gags on the rind, for he is not cynical enough to keep up the role. "Such games were for Rinehart, not me," he says, and he washes off the lipstick inscription he had meant to leave behind. Meanwhile, by doing a Rinehart, by pretending to agree with the Brotherhood in order to undermine it, he does in effect agree, and becomes a betrayer of the Harlem Brothers while working in his own interests. The irony of this role is that in the very moment of seeing Sybil's fantasy of the Black rapist he is himself attempting to live one. Rinehart the "spiritual technologist" is like the nameless 
Black Doctor in Barth's End of the Road, offering a "Mythotherapy" for roleparalysis which works only until one must face the consequences of his arbitrary action.

"Emerson" is another important name in Invisible Man, and one Ellison is acutely aware of as that of his own namesake. He deliberately uses it to undercut the conventional liberal attitude towards race relations, when the son of old Emerson (to suggest the historical continuity) tries to befriend the invisible man. Young Emerson tries to find him a place in the great Liberty Paint company just as Norton had tried to help him find a place in the American society, but both Norton and Emerson have an image of the Negro which limits their possibility of sharing any kind of reality with the invisible man. Emerson even wants to find a place for him in his own confused private life; after announcing that he had "a difficult session" with his analyst the evening before, Emerson goes on:

"Some things are just too unjust for words," he said, expelling a plume of smoke, "and too ambiguous for either speech or ideas. By the way, have you ever been to the Club Calamus?"

"I don't think I've ever heard of it, sir," I said.

"You haven't? It's very well known. Many of my Harlem friends go there. It's a rendezvous for writers, artists and all kinds of celebrities. There's nothing like it in the city, and by some strange twist it has a truly continental flavor."

The fey tone of this speech alone is enough to destroy what little respect we might have had for Emerson, but the Calamus Club reference takes it a bit further. The allusion is to the group of Whitman poems commonly called the Calamus Poems and dealing in a subtle but unmistakable way with the theme of homosexuality. In other words, here is still another fraternity or Brotherhood that is being offered the invisible man, and as the historical Emerson's ideas are debased in his 20th-century "son," Whitman's androgynously cosmic appetite is reduced to a stylish sexual mystique. Emerson makes it even more explicit later, when he says ". . . I'm Huckleberry, you see. . ." in hopes that the invisible man will be another Jim, and perhaps have read Leslie Fiedler. But the invisible man can't be Jim because he is already too busy being Huckleberry himself without knowing it.

Characters' names, and the club names, and the names of factories, places and institutions-even the names of things, like the Sambo doll-can be explored indefinitely in this novel. The Brotherhood has its parties at a place called the Chthonian Club, which is a classical reference comparable to that of the Sybils. The Chthonian realm belonged to the underground gods and spirits; and true power for Ellison is an underground influence as we learn from seeing Bledsoe and Brockway and Brother Jack in action, as well as the invisible man writing in his hole. Where does Ras get his name, with its vocal nearness to "race?" He gives it to himself, as the invisible man gives us the name we must call him by if we are to know him for what he is.

The invisible man in action is an image collector or symbolist, gathering up into 
his briefcase all the concrete emblems and reminders of his experience that can serve as clues to finding his real name and identity. The book itself is for the reader a similar container of images and clues expanded into actions and events. The first example of an action-as-image after the Prologue is the battle royal scene which opens the story. If we explored this scene far enough, we could find in it a prefiguration of almost everything else in the novel. Before the battle, the boys are forced to look at the naked blonde dancing for the whites. In the battle we see a group of half-naked Black boys, blindfolded, fighting each other in a ring for the entertainment of a group of white citizens. Afterwards they fight again, still among themselves, for the coins on the electrified rug. The coins they desire the most, the gold ones, turn out to be brass, but there are enough dollars to go around. Afterwards, the invisible man steps forward and gives his carefully-prepared speech (with one prophetic verbal slip) in which he defends the status quo of the Southern Negro who is trying to better himself through education in segregated schools. These are the bare bones of the scene, and they are suggestive in themselves. But if we look closer we can see much more. The naked white girl with golden hair suggests and prefigures the whole problem of money and sex. Her golden hair, like the fake golden coins, holds out a promise of a world which can never exist for the invisible man because it too is brass. The blindfolds on the boys are white blindfolds, and the darkness they are fighting in is a darkness imposed upon them by the white spectators who represent the whole society:

They were all there-bankers, lawyers, judges, doctors, fire chiefs, teachers, merchants, even one of the more fashionable pastors.

They unleash a great deal of violence in their brawl, but it is all directed against themselves, under the control of and for the amusement of this representative audience. During the brawl, one of the boys, the invisible man, loosens his blindfold enough so that he can make out a little bit of what is going on. And it is this one who comes forward afterwards to speak to the crowd, as the invisible man is speaking to us in the novel.

In the first few pages of the book, this scene seems to be primarily a description of what happened to a few people at a particular "smoker" in some small unidentified southern town. But as we read through the book, with this scene planted in our memories, we gradually realize that in it is condensed the whole world of the novel and almost all of the American society. The final scene, the race riot in Harlem, is in large part a repetition of the beginning scene, but one which we can more easily relate to the larger context it represents. Instead of the coins on the electrified rug, there is the safe on the third rail showering the streets with sparks. Instead of control being in ordinary citizens, it is in Brother Jack who represents their interests in controlling the Blacks. Instead of Tatlock and the invisible man battling it out at the end for supremacy, we have Ras and the invisible man, finally silencing his fanatic appeal to race by throwing a spear through his jaws. The riot is probably the most impressively sustained section of the whole novel. It is still carefully kept to the elements already prefigured in the brawl, yet expanded into a comic apocalypse of enormous proportions. It be- 
gins as a drunken orgy of consumer wish-fulfillment which is a fantasy Christmas ("At St. Nicholas the street lights were out.") and Fourth of July combined. At the peak of their frenzied rebellion the looters are still being controlled and manipulated by society's official symbol-makers:

"With all them hats in there and I'm going to come out with anything but a Dobbs? Man, are you mad? All them new, pretty-colored Dobbs?"

"Git a side of bacon, Joe," a woman called. "Git a side of bacon, Joe, git Wilson's."

Even Ras, who now calls himself the "Destroyer," has made himself up from the scrap heap of cultural detritus as Quixote made himself up from scraps and pieces of the old Romances. He is a composite of cowboy and African movies, equipped with stage-prop lion skin, spear and shield, "one of the kind you see them African guys carrying in the moving pictures. . .." Although they are rioting against society, no one knows how the riot got started, and the only damage they do is to themselves, in the pathetic burning-down of their own tenement. The only difference, save that of scale, is that at the end the invisible man does not step forward and give a speech prepared for him by the cultural myths, but instead disappears down his hole and creates a book which could only be written after he had recognized his invisibility.

On a smaller scale we can see the same kind of significance at work throughout the novel. In fact, there is a whole scale of images at work at almost every point in Invisible Man. Small ones, like the statue of the Founder removing the veil from the slave, but seen in such a way that it is impossible to tell whether it is being removed or put more firmly in place-echoed later by the invisible man's spotlight blindness as he makes his first official Brotherhood speech. Another is the recurring image of the mounted police, controlling the animal power of their black horses through a more efficient power and technique. In the invisible man's Brotherhood office is a map of the world with the figure of Columbus, reminding us that the real America is yet to be discovered, and that although there may be natives there, they will not be the natives we expected to find.

Some of these images seem to be quite clearly intended for the reader alone. Although they are registered through the eyes and consciousness of the invisible man, they are not noted by him as containing any special significance. In the El Toro bar, there are two bullfight posters which are described matter-of-factly along with the other miscellaneous contents of the room. The first poster shows a large black bull, being skillfully controlled by the matador. The other poster shows the tables turned, the bull finally discovering the illusion of the cape and tossing the matador high into the air. This is much like the fight between a prizefighter and a yokel described in the Prologue, where "the yokel, rolling about in the gale of boxing gloves, struck one blow and knocked science, speed and footwork as cold as a welldigger's posterior. The smart money hit the canvas. The long shot got the nod." The bullfight posters, and their echo of the prizefight, are a silent comment on the discussion going on in the bar between Brother Jack- 
who is trying to discipline him-and the invisible man. They are also a prediction of the outcome of the contest which will be fulfilled later in the novel.

Another condensed prefiguration is carefully suggested in the scene where Brother Tarp gives the invisible man his severed chain link, telling him the story of his limp which the doctors can't explain. For "saying no" to a man who wanted to take something from him, Tarp lost his wife, children and land and was sentenced to a life in prison on a chain gang. Nineteen years later, he said no again, and kept saying it until he broke the chain and left. Still limping, and still "looking for freedom," he gives the link to the invisible man because "it's got a heap of signifying wrapped up in it and it might help you to remember what we're really fighting against." At the moment of giving him the link, Tarp stops calling him son and calls him Brother "for the first time." The ceremony is

like a man passing on to his son his own father's watch, which the son accepted not because he wanted the old-fashioned time-piece for itself, but because of the overtones of unstated seriousness and solemnity of the paternal gesture which at once joined him with his ancestors, marked a high point of his present, and promised a concreteness to his nebulous and chaotic future. And now I remembered that if I had returned home instead of coming north my father would have given me my grandfather's old-fashioned Hamilton, with its long, burr-headed winding stem.

Tarp is both his spiritual father and brother, for they are looking for freedom together by saying no to slavery which has left its mark on each of them. Had the invisible man stayed in the South, in his own father's and grandfather's tradition, he would have remained a "burr-head" and a slave without knowing it.

Although some of these images are like guideposts for the reader, reminding him of the larger pattern of the novel, the larger ones are all in some degree meaningful to the invisible man, and there is a consistent pattern in his reaction to them. After each significant event, he gives a speech which summarizes his state of development as of that moment in the novel. The most naive speech is the one he gives after the brawl. In each succeeding recognition he is at least potentially more aware of who he is and what his experience means until the point where he is able to summarize the whole in a book which includes the other speeches. An example of the tentative progression of these speeches can be seen in Chapter 13. After having had his old identity wiped out through the boiler explosion, he begins to find a feeling of his own identity in a self-conscious but unashamed acceptance of some of the shabbier aspects of Harlem life. He eats a yam on the streets, without fear of being seen. When he comes on the eviction, he is at first embarrassed by the naked exposure of all the odds and ends of junk that tell the story of the life this old couple has lived. But gradually, as the furniture and debris pile up, he begins to realize that the belongings of the couple tell the story of his race, going all the way back to the Free Papers dated August, 1859. Even the consciousness of shame instilled in him from the day he was born can't obliterate the feelings of identity he gets from seeing these things: 
And it was as though I myself was being dispossessed of some painful yet precious thing which I could not bear to lose; something confounding, like a rotted tooth that one would rather suffer indefinitely than endure the short, violent eruption of pain that would mark its removal. And with this sense of dispossession came a pang of vague recognition.

The recognition is vague but intense, and the intensity shows up in the speech he makes and his willingness to fight for a feeling he still cannot define or fully accept.

Most of the actions and images I have been discussing have a plausible existence in the real world, and the important thing is the sensitivity of vision we bring to them. No matter how subtly calculated we can afterwards see the effect to be, there is always the impression of a real event while we are reading. There are places in Invisible Man, however, where the action seems decidedly secondary to the ideas Ellison is trying to convey, where the priority of the ideas dominates so that we can't read without the attempt to translate the action back into the ideas. In these cases Ellison seems to share Ishmael's attitude towards what he calls "hideous and intolerable allegory," not believing in it at all, yet unable to resist the comic indulgence of his appetite for it.

The clearest example here is in the factory hospital scene, where the doctors try to remake the invisible man into the mechanical man he had been before, the subservient southern Negro who died when he attacked Brockway in the boiler room. When he wakes in the hospital his mind is a blank, and he only gradually becomes aware that the doctors are trying to achieve a machine-induced prefrontal lobotomy that will return him to his previous state. The whole scene is presented as a return to childhood followed by rebirth, including the cutting of the umbilical cord (the electric cord attached to the stomach node), followed by an alcohol rubdown by an efficient nurse. "You're a new man," the doctors pointedly tell him. On the way home from the hospital the "new man" is metamorphosed into the new man, the Biblical Adam, who even predicts his own fall. "And I felt that I would fall, had fallen," he says, and then looks across the aisle of the subway car to see "a young platinum blonde nibbling at a red Delicious apple." 14

The same serio-comic intent is behind the 1,369 light bulbs that are made so much of in the Prologue. The light bulbs are his means of fighting the Monopolated Light and Power Company, and Ellison's way of illustrating the effects of a self-recognition on the power struggle that occupies most of the novel. After first finding his own light by burning the papers in the briefcase, he can begin to take revenge on the power monopoly that he has suffered under for so long. He is finally out of their control. He can't overthrow them, but he can undermine and weaken them by draining off part of their power. No writer would go to this extent for the sake of an idea alone, and there is a very pointed humor in much of Ellison's "allegory." The ironic, joking tone of the blues is continually showing through, as well as the pleasure Ellison obviously gets from the virtuoso manipulation of words. For a final example, consider the description of eating dessert in 
the hole. The invisible man is sitting there. He's blue, he's wondering why he's blue, and thinking what it means to be blue. And he's listening to Louis Armstrong playing and singing, "What Did I Do to Be so Black and Blue." He has just made a big point of being in the great American tradition, and now he is describing his favorite dessert of sloe gin and ice cream. As we visualize him pouring the red liquid over the white mound, we suddenly get the point of the color scheme he has been building up to emphasize his Americanism, and the submerged but deliberate joke helps to establish the tone of the whole Prologue. The effect is almost gratuitously clever, but Ellison is a fierce punster, and he can't always restrict himself to the obvious level of "I yam what I am," or turning Brother Tobitts into two bits.

He is also a prophetic writer, and that is why I must conclude with the envelope or frame which makes up the novel's beginning and end. The Prologue gives us a picture of the invisible man after he's finished writing the book, a picture of his present state. He has discovered that he is invisible, and taken the first step that he must take after the discovery. He has preserved his anger and his suffering by embodying it in art, and has even more fully grasped his identity in the process. But what is he to do with his identity after this, and after all the emphasis in the Epilogue on "the possibility that even an invisible man has a socially responsible role to play." We know that he is in hibernation, and we can't help wondering with him whether he will come up to find the smell of death or the smell of spring in the outside air. The invisible man doesn't know; he is prepared for a rebirth, and a new life, but has not yet been born into it. About 35 years ago Henry Roth published Call it Sleep. It was an extremely good novel, and for a first novel almost unbelievably good. Those were depression times, and it wasn't a protest novel, so there was not a great reaction, but those few who did appreciate it looked forward with anticipation to Roth's next work. While they waited, however, Roth disappeared, and has only recently been discovered, raising game birds near Augusta, Maine. With the rediscovery and tardy acclaim of Call it Sleep, many readers have naturally wondered why Roth has not written anything for so long. It turns out that he has been trying to write off and on, but can't. His problem, he says, is that "There is one theme I like above all others, and that is redemption, but I haven't the fable."

Invisible Man is clearly a prelude to and preparation for something like redemption, and therefore an extremely dangerous and difficult novel to follow. It may be that Ellison has written himself into a corner, or it may be that in his next novel he will find the fable for us. It seems to me that, if any of our contemporary writers can find it and express it, he can. But it has to be there first to be found, and whether it exists or not cannot be answered until it is found. Ellison has been working on his second novel for a long time now. Whatever he is doing, there is some evidence that it will be apocalyptic, that it will attempt to show us either the pattern of our redemption or of our destruction and continued frustration. We shouldn't forget that the alternative to a vision of redemption is carefully planted in the Prologue of Invisible Man. In his reflection on the brawl with the white man, the invisible man says: 
He, let us say, was lost in a dream world. But didn't he control that dream world-which, alas, is only too real!-and didn't he rule me out of it? And if he had yelled for a policeman, wouldn't $I$ have been taken for the offending one? Yes, yes, yes! Let me agree with you, I was the irresponsible one; for I should have used my knife to protect the higher interests of society. Some day that kind of foolishness will cause us tragic trouble. All dreamers and sleepwalkers must pay the price, and even the invisible victim is responsible for the fate of all. But I shirked that responsibility; I became too snarled in the incompatible notions that buzzed within my brain. I was a coward. . . .

\section{FOOTNOTES}

1 “To read such a book, for example, as Ralph Ellison's brilliant novel of 1953, Invisible Man, is to find, among one's richest satisfactions, the sense of immersion in all the concrete materialities of Negro life. One hears the very buzz and hum of Harlem in the racy, pungent speech of his West Indians and his native hipsters, and all the grotesquerie in his opening account of the dreary little backwater of a remote Southern Negro college has in it a certain kind of empirically absolute rightness. Indeed, the book is packed full of the acutest observations of the manners and idioms and human styles that comprise the ethos of Negro life in the American metropolis; and it gives us such a sense of social fact as can be come by nowhere in the stiffly pedantic manuals of academic sociology." Nathan A. Scott, Jr., "The Dark and Haunted Tower of Richard Wright," Black Expression, ed. Addison Gayle, Jr. (N.Y., 1969), p. 298.

2 Cf. Leroi Jones' "The Myth of a Negro Literature," where all Black writers are committed to mediocrity because "The literary and artistic models were always those that could be socially acceptable to the white middle class, which automatically limited them to the most spiritually debilitated imitations of literature available." (Black Expression, p. 192)

3 Worth noting for its grotesque insistence on this point, while at the same time contradicting it with a reputed social message ("Ellison's hero . . . is one of those catastrophic individuals of which society must rid itself before there can be peace and sanity."), is Nancy Tischler's "Negro Literature and Classic Form," Contemporary Literature, Summer 1969, Vol. 10, No. 3.

4 "Richard Wright's Blues" (Black Expression, p. 325).

5 "An Interview with Ralph Ellison," Tamarack Review, No. 32, Summer 1964, p. 11.

6 Black Expression, p. 324.

7 James Baldwin, "Notes for a Hypothetical Novel," Nobody Knows My Name (N.Y., 1961), pp. 148-49.

8 Black Expression, p. 316.

9 In "The Discovery of What it Means to be an American" Baldwin describes what he calls "a species of breakdown," and how he was oured of it by listening to Bessie Smith on records. He wrote Go Tell It on the Mountain "armed with two Bessie Smith records and a typewriter," as the invisible man writes his story listening to Louis Armstrong. 
There is a passage in Part III of Go Tell It on the Mountain where John Grimes undergoes an experience comparable to the invisible man's, in almost the same words that I have quoted from Ellison:

"He had heard it all his life, but it was only now that his ears were opened to this sound that came from the darkness, that could only come from darkness, that yet bore such sure witness to the glory of the light. And now in his moaning, and so far from any help, he heard it in himself-it rose from his bleeding, his cracked-open heart. It was a sound of rage and weeping which filled the grave, rage and weeping from time set free, but bound now in eternity; rage that had no language, weeping with no voicewhich yet spoke now, to John's startled soul, of boundless melancholy, of the bitterest patience, and the longest night; of the deepest water, the strongest chains, the most cruel lash; of humility most wretched, the dungeon most absolute, of love's bed defiled, and birth dishonored, and most bloody, unspeakable, sudden death. Yes, the darkness hummed with murder; the body in the water, the body in the fire, the body on the tree. John looked down the line of these armies of darkness, army upon army, and his soul whispered, Who are these?" (p. 228)

10 Tamarack Review, pp. 5-6.

11 It can also be the subject of a book, as in Sister Bernetta Quinn's Metamorphic Tradition in Modern Poetry, and Daniel Hoffman's Form and Fable in American Fiction.

12 In classical times sibyls or sibyllae were young maidens dwelling in lonely caves or by inspiring springs. Their function was to give forth prophetic utterances while under the influence of an enthusiastic frenzy.

13 Mailer's essay "The White Negro" is a more sophisticated or Hip version of this same fantasy. Baldwin, in "The Black Boy Looks at the White Boy," acknowledges that "to be an American Negro male is also to be a kind of walking phallic symbol: which means that one pays, in one's own personality, for the sexual insecurity of others."

14 This scene is reminiscent of Hart Crane's "For the Marriage of Faustus and Helen," where the poet-Faust imagines meeting Helen in a New York subway:

And yet, suppose some evening I forgot

The fare and transfer, yet got by that way

Without recall,-lost yet poised in traffic.

Then I might find your eyes across an aisle,

Still flickering with those prefigurations-

Prodigal, yet uncontested now,

Half-riant before the jerky window frame. 